\title{
The missed missing hole
}

\author{
Revelações de um canal ausente
}

Fábio Henrique de Gobbi Porto ${ }^{1,2}$, Mari-Nilva Maia da Silva' , João Roberto Sala Domingues², Gislaine Cristina Lopes Machado Porto ${ }^{3}$, Indran Davagnaman ${ }^{4}$, Ricardo Nitrini ${ }^{1}$

\begin{abstract}
At times in clinical neurology, the identification of a subtle clinical or radiological sign can lead to prompt diagnosis of a very rare or difficult case. We report on a patient who presented with untreatable headache and unilateral ptosis. Computed tomography (CT) scan of the head did not reveal any structural cause. Magnetic resonance angiogram showed absence of left internal carotid artery, which was eventually confirmed by a catheter angiography. Reviewing the case, it emerged that a feature on the initial CT scan "bone window" would have confirmed the diagnosis, had it been searched for: the underdeveloped carotid canal, which is a consequence and a marker of internal carotid artery agenesis.
\end{abstract}

Key words: carotid artery agenesis, Horner syndrome, carotid canal underdevelopment, computed tomography.

\section{RESUMO}

Em algumas circunstâncias, o reconhecimento de um sinal clínico ou radiológico sutil pode tornar simples o diagnóstico de um caso raro ou muito difícil em neurologia clínica. Relatamos o caso de uma paciente que apresentava cefaleia intratável e ptose palpebral unilateral. A tomografia computadorizada (TC) de crânio não permitiu identificar nenhuma causa estrutural. A ressonância magnética evidenciou ausência da artéria carótida interna esquerda, posteriormente confirmada por arteriografia convencional. Retrospectivamente, descobriu-se que um dado da janela óssea da primeira TC de crânio teria confirmado o diagnóstico, tivesse ele sido pesquisado: o hipodesenvolvimento do canal carotídeo, que é uma consequência e um marcador de agenesia da artéria carótida interna.

Palavras-Chave: agenesia da artéria carótida, síndrome de Horner, hipodesenvolvimento do canal carotídeo, tomografia computadorizada.

In everyday clinical practice, neurologists frequently encounter complex clinical cases in which a full analysis of several variants are essential to reach the right diagnosis. The resolution of a doubtful case may rely on the recognition of a very specific diagnostic clue. The objective of this report was to describe a case in which the prompt recognition of a very subtle imaging feature in the emergency room could have precluded further extensive diagnostic investigations.

\section{CASE REPORT}

A 34-year-old woman came into the Emergency department with a worsening headache. The symptoms had begun two weeks earlier, with a holocranial pulsatile headache that gradually worsened and became unbearable in the preceding three days. In association with the pain, she complained of nausea, vomiting and intolerance to movement, light and sound. As relevant medical history, she had dyslipidemia and was taking anphepramona for obesity. She had suffered occasional headaches in the past, but never of that intensity. She had already used several over the counter analgesics and nonsteroidal anti-inflammatory drugs with no relief.

Neurologic examination disclosed left eye ptosis, which she claimed to be preexisting (Fig A), confirmed on an old photograph. Cerebrospinal fluid analysis was normal. A magnetic resonance angiogram (MRA) of the internal carotid artery (ICA) demonstrated no signal within left ICA (Fig B)

${ }^{1}$ Behavioral and Cognitive Neurology Unit, Department of Neurology, Cognitive Disorders Reference Center (CEREDIC), Hospital das Clínicas of the University of São Paulo, São Paulo SP, Brazil;

${ }^{2}$ Department of Neurology, Santa Paula Hospital, São Paulo SP, Brazil;

${ }^{3}$ Department of Radiology, AC Camargo Hospital, São Paulo SP, Brazil;

4Department of Neuroradiology, The National Hospital for Neurology \& Neurosurgery, Queen Square, London, United Kingdom.

Correspondence: Mari-Nilva Maia da Silva; Centro de Referência em Distúrbios Cognitivos, Hospital das Clínicas da Universidade de São Paulo;

Rua Arruda Alvim 206; 05410-020 São Paulo SP - Brasil; E-mail: mari.n.maiadasilva@gmail.com

Conflict of interest: There is no conflict of interest to declare.

Received 20 March 2012; Received in final form 09 April 2012; Accepted 16 April 2012. 


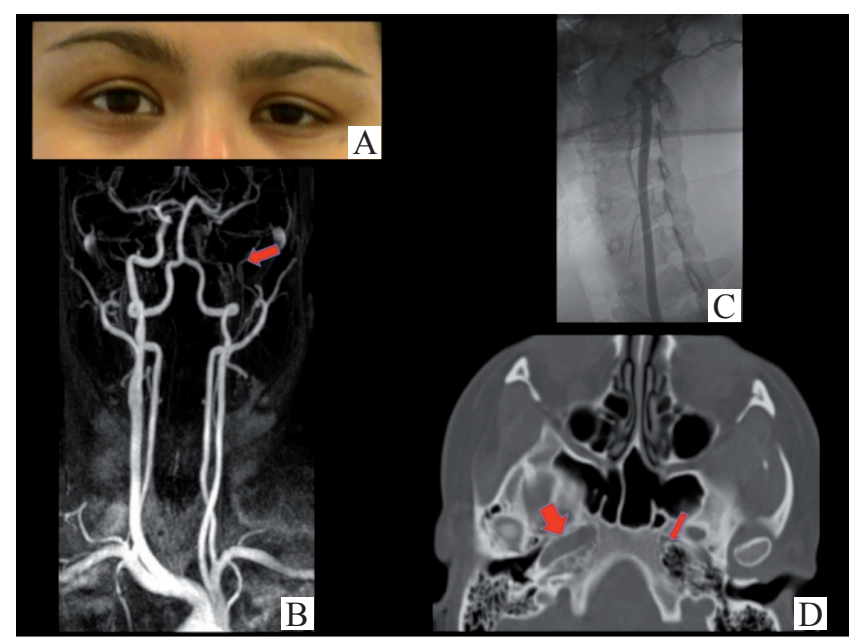

Fig. (A) patient picture, shows left eye ptosis; (B) magnetic resonance angiography on maximum-intensity projection image demonstrates the missing left internal carotid artery (arrow); (C) digital subtraction angiography confirm absence of internal carotid artery and shows normal common carotid artery and external carotid artery; (D) axial computed tomography on bone window revels an absent carotid canal in the left (thin arrow) and a normal carotid canal in the right (large arrow). Note the over pneumatization of the sphenoid bone on the left.

raising the possibility of an occlusive arterial dissection. To confirm this, a digital subtraction angiography (DSA) was requested, which ruled out arterial dissection, but confirmed the absence of the left ICA (Fig C). In addition to this, the DSA showed a fetal pattern of the Circle of Willis, an anatomic variant, in which the anterior and posterior communicating arteries supplied the left anterior and middle cerebral arteries. In retrospect, we had found a previous computed tomography $(\mathrm{CT})$, done at presentation in the Emergency department, demonstrating an underdeveloped left carotid canal (Fig D), a finding compatible with carotid agenesis, confirming the diagnosis of congenital Horner syndrome.

We reassured the patient of the diagnosis and started prophylactic treatment for migraine, the probable cause of her headaches. At follow-up, the headache frequency decreased, and attacks were well controlled with ibuprofen and sumatriptan.

\section{DISCUSSION}

Our case illustrates a clinical picture commonly seen in clinical practice, a new-onset headache with a focal neurologic sign. The headache and left-side ptosis led us to incisively search for a carotid dissection, although the patient claimed it to be old and the pain characteristics being more compatible with migraine. The misleading feature in this case was that MRA failed to show the left ICA, which made us suspect an arterial dissection and perform a DSA. What was overlooked was the underdevelopment of the left carotid canal on the Emergency department's CT. This finding was suggestive of carotid agenesis, which may present with congenital ptosis and headache.

The first report of ICA agenesis was by Tode in 1787, who found it on a postmortem examination ${ }^{1}$ with the first description of ICA agenesis using cerebral angiography by Verbiest in $1954^{2}$. Congenital ICA anomalies are rare, occurring in less than $0.01 \%$ of the population ${ }^{2}$, and demonstrated in less than $0.4 \%$ on cerebral angiograms ${ }^{3}$. The development of the primordial ICAs occurs from the terminal segment of the dorsal aorta and the third aortic arch arteries by the fourth week, but the skull base does not begin to form until fifth to sixth week of fetal life. The carotid canal develops afterwards and in dependence of the primordial ICA. Therefore, if the embryonic primordium of the ICA fails to develop or involutes early in embryonic development, in consequence, it is not present during the skull base formation, leading to underdevelopment or no development of the carotid canal ${ }^{4,5}$.

Most of the patients with ICA agenesis are asymptomatic, some are discovered incidentally, or the diagnosis is suggested by the finding of collateral circulation ${ }^{34,6-8}$. It is thought that the development of these collaterals increases the risk of aneurysm formation and subarachnoid haemorrhage ${ }^{7}$, as well as hemodynamic disturbance harbouring a higher risk for ischemic stroke ${ }^{6}$. Possible symptomatic presentations include convulsions, transient ischemic attacks, stroke, pulsatile tinnitus and headache ${ }^{5,6}$. The importance of diagnosis remains in the fact that there may be associations with intracranial vascular abnormalities, including aneurysm, subarachnoid hemorrhage, anomalous vascular anastomoses, cerebral hypoplasia, hemangiomas and encephalocele ${ }^{4}$. ICA agenesis can be one of the vascular abnormalities constituting the PHACES (posterior fossa malformations, hemangiomas, arterial malformations, coarctation of the aorta/ cardiac defects, eye abnormalities and sternal defects) syndrome $^{9}$, and there also are reports on its associations with neurofibromatosis types I and $\mathrm{II}^{10,11}$.

Congenital Horner's syndrome is rarely described in association with ICA agenesis ${ }^{7,12,13}$. The Horner's syndrome results from interruption of the sympathetic nerve to the eye, upper lid and facial glands at any point in its course. It is postulated to occur with carotid agenesis, because the ocular sympathetic nerve runs along the ICA. Thus, the absence of the latter may causes a sympathetic denervation of the eye.

In this case, the "Tricks of the trade" would have been a careful scrutiny of the CT image, not just the "brain window", but also the "bone window", mainly of the skull base. CT scan of the skull base showing a hypoplastic or absent carotid canal differentiates congenital absence of the ICA from other causes of stenosis-like dissection, atherosclerosis or fibromuscular dysplasia ${ }^{7}$. In doing so, we need to consider carotid agenesis in the differential diagnosis of complete or partial Horner syndrome, as, after all, we only see what we look for. 


\section{References}

1. Midkiff RB, Boykin MW, McFarland DR, Bauman JA. Agenesis of the internal carotid artery with intercavernous anastomosis. AJNR Am J Neuroradiol 1995;16:1356-1359.

2. Given CA 2nd, Huang-Hellinger F, Baker MD, Chepuri NB, Morris PP. Congenital absence of the internal carotid artery: case reports and review of the collateral circulation. AJNR Am J Neuroradiol 2001;22:1953-1959.

3. Dinç H, Alioglu Z, Erdöl H, Ahmetoglu A. Agenesis of the internal carotid artery associated with aortic arch anomaly in a patient with congenital Horner's syndrome. AJNR Am J Neuroradiol 2002;23:929-931.

4. Quint DJ, Silbergleit R, Young WC. Absence of the carotid canals at skull base CT. Radiology 1992;182:477-481.

5. Ryan FH, Kline LB, Gomez C. Congenital Horner's syndrome resulting from agenesis of the internal carotid artery. Ophthalmology 2000;107:185-188

6. Cohen JE, Gomori JM, Leker RR. Internal carotid artery agenesis: diagnosis, clinical spectrum, associated conditions and its importance in the era of stroke interventions. Neurol Res 2010;32:1027-1032.

7. Farhat W, Ahdab R, Hosseini H. Congenital agenesis of internal carotid artery with ipsilateral Horner presenting as focal neurological symptoms. Vasc Health Risk Manag 2011;26:37-40.
8. Neves WS, Kakudate MY, Cêntola CP, Garzon RG, Poça d’Água A, Sances R. Agenesia da artéria carótida interna: relato de caso. Radiol Bras 2008;41:63-66.

9. Metry DW, Hawrot A, Altman C, Frieden JJ. Association of solitary segmental hemangiomas of the skin with visceral hemangiomatosis. Arch Dermatol 2004;140:591-596.

10. Chen MC, Liu HM, Huang KM. Agenesis of the internal carotid artery associated with neurofibromatosis type II. AJNR Am J Neuroradiol 1994;15:1184-1186.

11. Barcik U, Quijano-Roy S, Caballero-Martin MA, Viaño J, Pascual-Castroviejo I. Type | neurofibromatosis associated with internal carotid artery hypoplasia. An Esp Pediatr 1999;51: 687-689.

12. Ibrahim M, Branson HM, Buncic JR, Shroff MM. A case of Horner syndrome with intermittent mydriasis in a patient with hypoplasia of the internal carotid artery. AJNR Am J Neuroradiol 2006;27: $1318-1320$

13. Fons C, Vasconcelos M, Vidal M, et al. Agenesis of internal carotid artery in a child with ipsilateral Horner's syndrome. J Child Neuro 2009;24:101-104 